\title{
Lipid Surface Films: Interaction of Bacteria with Free Fatty Acids and Phospholipids at the Air/Water Interface
}

\author{
By S. KJELLEBERG* AND T. A. STENSTRÖM \\ Department of Marine Microbiology, Botanical Institute, University of Göteborg, \\ Carl Skottsbergs Gata 22, S-413 19 Göteborg, Sweden
}

(Received 23 April 1979; revised 27 August 1979)

The interactions of bacteria, mainly Serratia marinorubra and Pseudomonas halocrenaea, with different lipid surface films were examined employing the surface balance technique and particle electrophoresis. Three free fatty acids as well as octadecylamine, and two diacylphosphatidylcholines were used as monolayer films with phosphate and ammonium acetate buffers as subsurface solutions. The following factors were involved in the interaction: the architecture of the surface film, the charge carried by both the bacteria and the film, hydrophobic interaction, and probably enzyme activity. The presence of $\mathrm{Ca}^{2+}$ seemed to be necessary for interfacial phospholipase activity.

\section{INTRODUCTION}

All interfaces tend to accumulate organic amphiphilic material since this generally lowers the free energy of the system (Davies \& Rideal, 1963). The surface microlayers at the air/ water interface of the sea have been studied extensively with respect to both chemistry and microbiology and have been found to consist of three upper strata: the lipid film, the polysaccharide-protein complex and the bacterioneuston layer (Kjelleberg et al., 1979; MacIntyre, 1974; Norkrans, 1979). Evidence from field and model system experiments suggests a positive correlation between the number of micro-organisms and the amount of lipids on the surface (Norkrans \& Sörensson, 1977).

The nature of the microbial interaction, which is of general interest for most interfaces, has not been fully revealed. This interaction can conveniently be studied with the surface balance technique (Kjelleberg et al., 1976), where amphiphilic materials are spread on the surface of an aqueous subphase to form a monomolecular layer (Gaines, 1966). The adhesion of bacteria or molecules to the surface is indicated by an increase in the surface pressure at a given area per molecule $(A)$, where the surface pressure $(\pi)$ is defined as $\pi=\gamma_{0}-\gamma$, where $\gamma_{0}$ is the interfacial tension in the absence of the film and $\gamma$ is the interfacial tension in the presence of the film. Dissolution of the film (e.g. as a result of enzymic activity) decreases the film pressure. The bacterial surface charge can be determined from the electrophoretic mobility of the bacteria, measured in a particle electrophoresis apparatus. These techniques have been used to study the interactions of bacteria with surface films of lipids.

\section{METHODS}

Bacteria. The test bacteria used were Serratia marinorubra (ATCC 19729), Serratia marcescens (EF 190), Pseudomonas halocrenaea (ATCC19712), Escherichiacoli B (ATCC 23226), Vibrio haloplanktis (ATCC14393) and Bacillus subtilis (ATCC 6051). Escherichia coli B, V. haloplanktis, and B. subtilis were included as reference strains in the particle electrophoresis measurements. All strains were kept as stock cultures $\left(4^{\circ} \mathrm{C}\right)$ and grown in the same medium, containing: peptone, $5.0 \mathrm{~g}$; yeast extract, $1.0 \mathrm{~g} ; \mathrm{FePO}_{4}, 0.01 \mathrm{~g}$; salt solution, $750 \mathrm{ml}$; distilled water, $250 \mathrm{ml}$. The salt solution had the following composition: $\mathrm{NaCl}, 23.5 \mathrm{~g} ; \mathrm{Na}_{2} \mathrm{SO}_{4}$, 
$1.96 \mathrm{~g} ; \mathrm{NaHCO}_{3}, 0.10 \mathrm{~g} ; \mathrm{KCl}, 0.33 \mathrm{~g} ; \mathrm{KBr}, 0.05 \mathrm{~g} ; \mathrm{MgCl}_{2} .6 \mathrm{H}_{2} \mathrm{O}, 2.49 \mathrm{~g} ; \mathrm{CaCl}_{2} .2 \mathrm{H}_{2} \mathrm{O}, 0.55 \mathrm{~g} ; \mathrm{SrCl}_{2} .6 \mathrm{H}_{2} \mathrm{O}$, $0.01 \mathrm{~g} ; \mathrm{H}_{3} \mathrm{BO}_{3}, 0.01 \mathrm{~g}$; distilled water, 11 . Spontaneous non-pigmented mutants of $S$. marcescens were isolated and studied.

Bacteria were grown at $20^{\circ} \mathrm{C}\left(\right.$ E. coli $\mathrm{B}$ at $\left.37^{\circ} \mathrm{C}\right)$ to the mid-exponential phase and then centrifuged at $5000 \mathrm{~g}$ for $10 \mathrm{~min}$. The cells were washed twice and resuspended in an appropriate buffer. Control measurements in the surface balance and the particle electrophoretic apparatus showed that the washing procedure completely removed the medium. Unless otherwise stated, bacterial concentrations of $10^{6} \mathrm{ml}^{-1}$ were used.

Serratia marinorubra and $P$. halocrenaea were tested for phospholipolytic activity on agar plates with the basal composition: peptone, $0.5 \mathrm{~g}$; yeast extract, $0.3 \mathrm{~g}$; concentrated egg yolk emulsion, $0.5 \mathrm{ml}$ (added after sterilization); agar, $1.5 \mathrm{~g}$; distilled water, $100 \mathrm{ml}$ (Oxoid Manual, 1967). Two $\mathrm{NaCl}$ concentrations were also compared: 1 and $2 \cdot 3 \%(\mathrm{w} / \mathrm{v})$. Phospholipase producers render the media opaque.

Chemicals. Oleic acid was obtained from Carlo Erba (Milano, Italy), all other acids were from Merck (Darmstadt, Germany), octadecylamine was from Roth (Karlsruhe, Germany), dioctanoyl-L- $\alpha$-phosphatidylcholine and egg phosphatidylcholine were from Supelco (Bellefonte, Pennsylvania, U.S.A.). The fatty acid constituents of egg lecithin were determined by gas-liquid chromatography of their methyl esters on a column packed with $5 \%(\mathrm{w} / \mathrm{w})$ butan-1,4-diol succinate on Chromosorb. The film substances were dissolved in hexane/ethanol $(9: 1, \mathrm{v} / \mathrm{v})$. Lipase (crude extract) and sodium dodecyl sulphate were obtained from Serva (Heidelberg, Germany). Two types of $0.2 \mathrm{M}$ buffer solution, $\mathrm{pH} 7 \cdot 4$, were used as suspending media for the bacteria and as bulk solution: $\mathrm{Na}_{2} \mathrm{HPO}_{4} / \mathrm{KH}_{2} \mathrm{PO}_{4}$ buffer, ionic strength $(I)=0 \cdot 02$, and an ammonium acetate buffer, $I=0 \cdot 02$. Unless otherwise stated, the phosphate buffer was used. The water used for the experiments and in the buffers was deionized, distilled twice, and passed through a Millipore Super-Q system with ion-exchange and activated carbon columns. All chemicals were of analytical grade. All glassware was carefully cleaned in concentrated dichromic acid, alcohol and hexane, in that order.

Surface balance technique. The surface tension was measured with a glass plate suspended from a torsion wire (Wilhelmy technique) while the surface film was subjected to a continuously increasing compression with a Teflon barrier (Gaines, 1966). The film was thereby changed from a 'gaseous' state with a large average area per molecule, via an expanded liquid state, to a condensed monolayer in which the molecules were tightly packed. The small deflection of the plate was sensed by a force transducer and recorded synchronously with the movement of the barrier. The apparatus was constructed by Dr Håkan Löfgren at the Department of Structural Chemistry, University of Göteborg, Sweden.

The glass trough used was first cleaned with freshly prepared concentrated dichromic acid for $20 \mathrm{~min}$ and rinsed several times with water. The edges of the trough were made hydrophobic with a uniform coat of pure paraffin and it was then filled to the rim with the appropriate buffer, the aqueous subphase. The surface was swept several times with Teflon barriers. A bacterial suspension $(2 \mathrm{ml})$ was carefully distributed into the solution with a syringe. The film-forming solution was then spread dropwise on to the surface using an Agla micrometer syringe with the needle held close to the surface. Usually one-sixth of the amount giving a condensed monolayer state at final compression was spread. The compression of the suface film was carried out $2 \mathrm{~h}$, or in some experiments $10 \mathrm{~h}$, after spreading the lipid films. The temperature was kept at $20 \pm 0.5^{\circ} \mathrm{C}$. Each experiment was repeated at least three times and consisted of one calibration test with the film substance alone and one test with bacteria and film. For enzyme activity measurements, $\mathrm{CaCl}_{2}$ and $\mathrm{BaCl}_{\mathbf{2}}$ were mixed in the phosphate buffer solution prior to the experiment to a final concentration of $1 \mathrm{~mm}$. Control measurements without any film substance gave the same result regardless of whether bacteria were mixed in the subphase or not.

Particle electrophoretic measurements. The mobilities of the bacterial cells were determined using a Rank Mark II particle microelectrophoresis apparatus (Rank Brothers, Bottisham, Cambs.) supplied with a flat glass cell and black platinum electrodes. The glass cell was cleaned in the same way as the surface balance trough. The procedure recommended by Shaw (1969) was followed. Observations were made at a marked place in the cell and all readings were taken by the same person. All measurements were run at $25 \pm 0 \cdot 1^{\circ} \mathrm{C}$. The applied voltage was $30 \mathrm{~V}$. The bacteria were generally made to move $50 \mu \mathrm{m}$ in each direction. At least 50 cells were followed in both directions. Cells of $S$. marinorubra were very motile and were therefore held for 10 min at 45 to $50^{\circ} \mathrm{C}$ in a water bath before the measurement. This treatment had no lethal effect and the motility returned within $1 \mathrm{~h}$.

RESULTS

\section{Monolayer studies}

Free fatty acids. Pseudomonas halocrenaea and Serratia marinorubra were studied in interaction experiments with palmitic acid $\left(C_{16: 0}\right)$, stearic acid $\left(C_{18: 0}\right)$ and oleic acid $\left(C_{18: 1}\right)$, all with a net negative charge at $\mathrm{pH} 7 \cdot 4$ (Table 1 ). The greatest interaction occurred between 


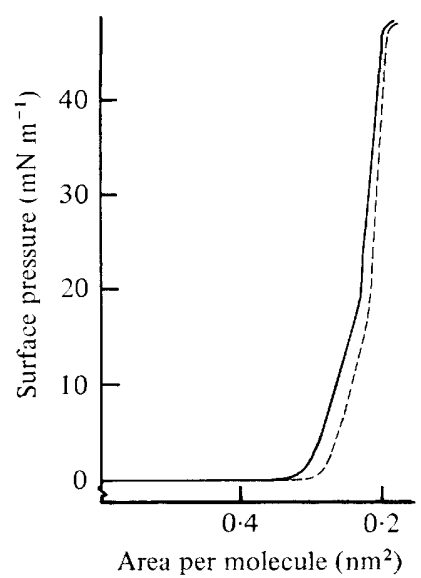

Fig. 1

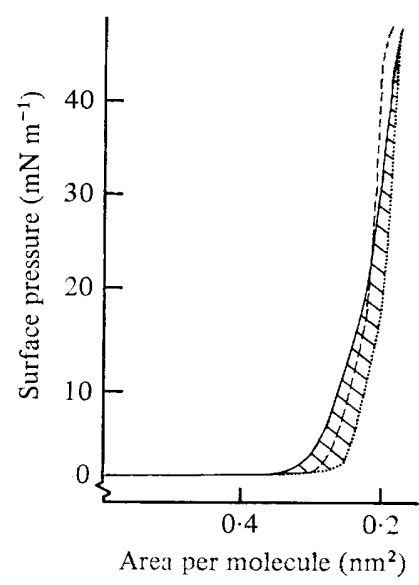

Fig. 2

Fig. 1. Surface pressure as a function of molecular area for a monolayer of palmitic acid on phosphate buffer solution with $(-)$ or without (--) cells of Serratia marinorubra.

Fig. 2. Surface pressure as a function of molecular area for a monolayer of palmitic acid on phosphate buffer solution with (-) or without (--) cells of Pseudomonas halocrenaea. The crosshatched area represents the overall adhesion of cells after compensating for the film loss at the point of monolayer collapse.

Table 1. Degree of interaction between test bacteria and monolayered surface films using the surface balance technique

One-sixth of the amount giving a condensed monolayer state at final compression was spread. The aqueous phase consisted of phosphate buffer, $0.02 \mathrm{M}, \mathrm{pH} \mathrm{7 \cdot 4}$. The results are given as the percentage change in the area under the surface pressure isotherm \pm standard deviation. Values without a sign represent the apparent adhesion and a minus sign means film loss. Changes of less than $5 \%$ are within experimental error.

Change in the area under the surface pressure isotherm (\%)

Test organism

\begin{tabular}{lllllc}
\multicolumn{5}{c}{ Film-forming substance* } \\
$\mathrm{C}_{16: 0}$ & \multicolumn{1}{c}{$\mathrm{C}_{18: 0}$} & $\mathrm{C}_{18: 1}$ & ODA & EPC & DOPC \\
$14 \pm 6,-10 \pm 6$ & $27 \pm 7,-5 \pm 4$ & $<5$ & $43 \pm 1$ & $40 \pm 0$ & $27 \pm 4$ \\
$(60) \dagger$ & $(84) \dagger$ & & & & $5 \pm 4 \%$ \\
$37 \pm 4$ & $35 \pm 11$ & $21 \pm 16$ & $90 \pm 12$ & $29 \pm 5$ & $33 \pm 5$
\end{tabular}

Serratia marinorubra

* $\mathrm{C}_{16: 0}$, Palmitic acid; $\mathrm{C}_{18: 0}$, stearic acid; $\mathrm{C}_{18: 1}$, oleic acid; ODA, octadecylamine; EPC, egg phosphatidylcholine; DOPC, dioctanoylphosphatidylcholine.

$\dot{\dagger}$ Values in parentheses represent the overall adhesion of cells with the lipid film after compensating for the film loss at the point of monolayer collapse.

$\ddagger$ With the addition of $1 \mathrm{~mm}-\mathrm{CaCl}_{2}$.

S. marinorubra and the condensed films of stearic and palmitic acids. In a previous study with the liquid expanded film of oleic acid, $S$. marinorubra caused an increase of the surface pressure at a high $\mathrm{pH}$ of 10.5 ; at $\mathrm{pH} 8.7$ no increase could be detected (Kjelleberg et al., 1976). The present equipment was more sensitive (Table 1).

Figure 1 illustrates the interaction of $S$. marinorubra with palmitic acid. Both the loosely packed film (the 'gaseous' state) and, to a minor extent, the condensed monolayer were affected. This finding modifies the earlier conclusions of Kjelleberg et al. (1976) that forces binding bacteria to free fatty acid films are not strong enough to penetrate a condensed monolayer.

Pseudomonas halocrenaea exhibited adhesion with both palmitic and stearic acids but also caused loss of film. Figure 2 shows these two effects as well as the overall adhesion of 
Table 2. Electrophoretic mobility of test bacteria in a phosphate buffer $(p H 7 \cdot 4, I=0 \cdot 02)$ at $25 \pm 0 \cdot 1{ }^{\circ} \mathrm{C}$

The results show mean values \pm standard deviations, calculated from the mobilities of more than 50 cells in both directions.

Test organism

Bacillus subtilis

Escherichia coli $\mathrm{B}$

Pseudomonas halocrenaea

Serratia marcescens, pigmented

Serratia marcescens, non-pigmented

Serratia marinorubra

Vibrio haloplanktis

$\begin{array}{cc}\begin{array}{c}\text { Electrophoretic mobility } \\ \left(\mu \mathrm{m} \mathrm{cm} \mathrm{s} \mathrm{cm}^{-1} \mathrm{~V}^{-1}\right)\end{array} \\ \begin{array}{c}\text { Cells from } \\ \text { exponential } \\ \text { growth phase }\end{array} & \begin{array}{c}\text { Cells from } \\ \text { stationary } \\ \text { growth phase } \\ 3.98 \pm 0.48\end{array} \\ 2.05 \pm 0.78 & 3.98 \pm 0.71 \pm 0.22 \\ 2.65 \pm 0.27 & 2.58 \pm 0.58 \\ 3 \cdot 14 \pm 0.41 & 3.36 \pm 0.33 \\ 3.58 \pm 0.20 & 2.74 \pm 0.37 \\ 3.06 \pm 0.36 & 4.57 \pm 0.23 \\ 4.54 \pm 0.25 & \end{array}$

the bacteria after compensating for the film loss observed at the point of near-condensed monolayer collapse. The compensated adhesion values (Table 1) were as high as $60 \%$ (palmitic acid) and $84 \%$ (stearic acid). With oleic acid the interaction of $P$. halocrenaea was less than 5\% and not reproducible. Myristic acid $\left(\mathrm{C}_{14: 0}\right)$ and palmitoleic acid $\left(\mathrm{C}_{16: 1}\right)$ did not form stable surface films during the equilibration time.

Diacylphosphatidylcholines. Two phospholipids, egg phosphatidylcholine (EPC) and dioctanoyl-L- $\alpha$-phosphatidylcholine (DOPC), both zwitterionic at $\mathrm{pH} 7 \cdot 4$, were tested for interaction with $P$. halocrenaea and $S$. marinorubra. Gas chromatographic analysis showed that egg lecithin contained the following fatty acids: $\mathrm{C}_{16: 0}(31.4 \%), \mathrm{C}_{18: 0}(16.6 \%), \mathrm{C}_{18: 1}$ $(34.9 \%)$ and $C_{18: 2}(15 \cdot 5 \%)$, with very small amounts of $C_{14: 0}(0.90 \%)$ and $C_{16: 1}(1.5 \%)$. The acyl chains in DOPC are short enough to be significantly dissolved in the water phase if enzymic deacylation occurs. Both bacteria increased the areas under the $\pi-A$ isotherms of these films (Table 1), affecting the loosely packed film state for both EPC and DOPC. Serratia marinorubra also affected the condensed monolayers. For DOPC we also used a $10 \mathrm{~h}$ equilibration time, resulting in bigger increases in the surface pressure.

Pseudomonas halocrenaea showed no clear phospholipase activity in these tests. However, the system DOPC/P. halocrenaea gave rise to a lower surface pressure when $\mathrm{Ca}^{2+}$ was present (Table 1), whereas $\mathrm{Ba}^{2+}$ at the same concentration did not lower the surface pressure. In plate tests for enzyme activity $P$. halocrenaea exhibited a strong and $S$. marinorubra a very weak phospholipolytic activity with the basal medium (no $\mathrm{NaCl}$ added).

Octadecylamine. To elucidate the importance of the polar head groups and their charges

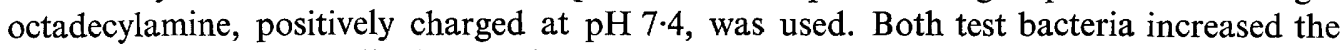
surface pressure markedly (Table 1). Similar tests with $E$. coli B and differently charged films gave about the same effects. With an ammonium acetate buffer, however, the adhesion between octadecylamine and $P$. halocrenaea was less than $5 \%$; no film loss occurred with this buffer in the system $P$. halocrenaea $/ \mathrm{C}_{18: 0}$.

\section{Particle electrophoretic studies}

Studies of the bacterial surface charge were usually done with cells from both the exponential and stationary phases. All bacteria except $E$. coli $\mathrm{B}$, which showed large variations, exhibited high mobilities (Table 2). For the two Serratia species, cells from the stationary phase tended to have a lower surface charge than cells growing exponentially.

The mobility of $P$. halocrenaea was unaffected by exposure to lipase or sodium dodecyl sulphate, but $2 \mathrm{mM}-\mathrm{CaCl}_{2}, \mathrm{MgCl}_{2}$ or $\mathrm{SrCl}_{2}$ reduced the cell mobility to 70 to $75 \%$ of the original value. No clear differences could be detected among the effects of the three ions. 
Consistent with the characteristic effects of sodium dodecyl sulphate reported by Hill et al. (1963), $P$. halocrenaea is not dependent on hydrophobic interaction. At the concentrations used $\left(10^{-4}\right.$ to $\left.10^{-5} \mathrm{M}\right)$, they found a clear change in mobility and correlation with the amount of lipid extracted from the bacterial cell walls.

The influence of pigmentation was studied with cells of $S$. marcescens since this species, which is less motile than $S$. marinorubra, can be used without heat treatment. Three different isolates of spontaneously mutated pigment-free $S$. marcescens were tested. The pigmented and non-pigmented strains all gave mobility values of the same order but the non-pigmented strains tended to have higher mobilities. For both types the stationary phase cells had lower mobility than the exponential phase cells.

\section{DISCUSSION}

Bacterial interaction with lipid films, as revealed by the surface balance, is influenced by several factors, partly resembling those mechanisms of bacterial attraction to interfaces reviewed by Marshall $(1975,1976)$. First is the architecture of the film: if the surface molecules are sufficiently separated to prevent interchain reactions, the possibility for bacterial interaction is greatly enhanced, as was shown by additional experiments with the spreading of fewer molecules of $\mathrm{C}_{16: 0}$. Similar reasoning explains the stronger bacterial influence on the condensed $\mathrm{C}_{16: 0}$ and $\mathrm{C}_{18: 0}$ film than on the $\mathrm{C}_{18: 1}$ film. For the two straight chain acids, lateral adhesion will more easily result in island formation, effectively lowering the surface density, than for oleic acid with its double bond. Shah \& Schulman (1967) discuss similar processes for the penetration of enzyme molecules into a monolayer. Like oleic acid, the phospholipids form $\pi-A$ curves characteristic of expanded films, as each molecule has a larger molecular area at low surface pressure. The interaction of bacteria with EPC and DOPC leads to changes in the curve shape that demonstrate alterations of both the loosely packed and the condensed monolayer film, where the surface pressure had a significantly higher value at a corresponding molecular area. The bacteria are not forced out of the film completely and penetrate the condensed monolayer.

Secondly, both bacterial and surface film charges play a part in the interaction. Bacteria carry a characteristic negative charge, varying from species to species (Longton et al., 1975). This provides an explanation for (i) the large increase in surface pressure caused by changing from negatively-charged fatty acid films to octadecylamine films, which are positively charged at $\mathrm{pH} 7 \cdot 4$; (ii) the fact that for an octadecylamine film a larger surface pressure increase is observed with cells of $S$. marinorubra than with $P$. halocrenaea, for which the electrophoretic measurements indicated smaller negative charge; and (iii) the higher overall adhesion to monolayered stearic acid (and palmitic acid) of $P$. halocrenaea than of $S$. marinorubra.

Specific surface molecules such as the pyrrol-containing prodigiosins, pigments characteristic of the genus Serratia, may also play a role in the interaction. Non-pigmented mutant cells and cells from early growth phases of Serratia, known to be less pigmented than stationary phase cells (Williams et al., 1976), bear a higher negative charge. Blanchard \& Syzdek (1978) have reported variations in the jet drop concentration factor $(C)$ for $S$. marcescens cells. For the top jet drop, $C$ was 200 for red cells and 0.3 for white cells, where $C$ was the bacterial concentration in a jet drop from bursting bubbles relative to that in the subsurface water.

The surface charge, however, cannot be wholly decisive for the interaction of the bacterium since strong effects occurred between the bacteria and the zwitterionic phospholipids. This indicates a third factor of importance, the hydrophobic interaction. Since part or all of the outer surface of some bacteria is hydrophobic it is reasonable to suppose that such bacteria are rejected from the aqueous phase and attracted towards any non-aqueous phase (Marshall, 1976). At low surface pressures, bacterial surface groups are probably mixed with the non-polar parts of the surface film. Furthermore, Acholeplasma laidlawii, which 
lacks a cell wall, interacts markedly with a film of dipalmitoylphosphatidylcholine (Kjelleberg et al., 1976). Since the lipid bilayer of the Acholeplasma membrane is accessible, this is to be expected.

Finally, we consider enzymic activity revealed by reduced film pressures. The film loss observed for free fatty acids using the phosphate buffer solution can probably be attributed to $\beta$-oxidative activity. When an acetate buffer was used as bulk solution, $P$. halocrenaea interacted only weakly with a monolayer of stearic acid or octadecylamine. The bulk acetate ions might inhibit the activity of the enzyme or be utilized by the cells. By analogy, sites of $E$. coli have been shown to act as receptors for specific ionized carboxyl groups of inorganic and organic acids (Dawes, 1977).

Pseudomonas halocrenaea was able to split phospholipids when tested on agar plates. However, when using the DOPC film on an unsupplemented buffer solution as subsurface in the surface balance, no film loss was observed unless $\mathrm{Ca}^{2+}$ was added. $\mathrm{Ca}^{2+}$ has previously been shown to act as an activator of phospholipases, while other divalent ions such as $\mathrm{Ba}^{2+}$ and $\mathrm{Sr}^{2+}$ are competitive inhibitors (e.g. Pieterson et al., 1974; Proulx \& Fung, 1969). The enzyme activity is optimized at a critical surface pressure (Dawson, 1969; Verger et al., 1976; Zografi et al., 1971). Thus, the hydrolysis may act more intensively under surface compression than during the $2 \mathrm{~h}$ equilibration. The $\mathrm{Ca}^{2+}$ effect is not a non-specific counter-ion effect since the changes in mobility after exposure to $\mathrm{Ca}^{2+}, \mathrm{Mg}^{2+}$ and $\mathrm{Sr}^{2+}$ were the same.

Further knowledge of the interaction between micro-organisms and the surface film could be obtained by using polymers and proteins as film-forming material or by creating monolayers also containing substances from the cell envelope.

We would like to thank Res Prof Birgitta Norkrans at this department, Dr H. Löfgren (Department of Structural Chemistry, University of Göteborg) and R. Andersson (Swedish Food Institute, Göteborg) for their help and advice on this work. This investigation was supported by the Swedish Natural Science Research Council, grants B 0201-022.

\section{REFERENCES}

Blanchard, D. C. \& Syzdek, L. D. (1978). Seven problems in bubble and jet drop researches. Limnology and Oceanography 23, 389-400.

Davies, I. T. \& Rideal, E. K. (1963). Interfacial Phenomena. London: Academic Press.

DAwES, J. (1977). The function of carboxyl groups in phage $\mathrm{T}_{4}$ adsorption. FEMS Microbiology Letters 1, 187-192

DAwson, R. M. C. (1969). Enzymatic hydrolysis of monomolecular layers. Methods in Enzymology 14, 633-648.

GAINES, G. L., JR (1966). Insoluble Monolayers at Liquid Gas Interfaces. New York: Interscience Publishers.

HiLL, M. J., JAMES, A. M. \& MAXTED, W. R. (1963). Some physical investigations of the behaviour of bacterial surfaces $X$. The occurrence of lipids in the streptococcal cell wall. Biochimica et biophysica acta 75, 414-424.

KJelleberg, S., Norkrans, B., Löfrgren, H. \& LARSSON, K. (1976). Surface balance study of the interaction between microorganisms and lipid monolayer at the air/water interface. Applied and Environmental Microbiology 31, 609-611.

Kjelleberg, S., Stenström, T. A. \& Odham, G. (1979). Comparative study of different hydrophobic devices for sampling lipid surface film and adherent microorganisms. Marine Biology 53, 21-25.
Longton R. W. Cole J. S. \& QuinN P. F. (1975). Isoelectric focusing of bacteria: species location within an isoelectric focusing column by surface charge. Archives of Oral Biology 20, 103-106.

MACINTYRE F. (1974). The top millimeter of the ocean. Scientific American 20, 62-77.

MARSHALL K. C. (1975). Clay mineralogy in relation to survival of soil bacteria. Annual Review of Phytopathology 13, 357-373.

Marshall K. C. (1976). Interfaces in Microbial Ecology. Cambridge: Harvard University Press.

NoRKRANS, B. (1979). Role of surface microlayers. In Proceedings of the Workshop: Microbial Degradation of Pollution in Marine Environments. Edited by A. W. Bourquin \& P.H. Pritchard. Gulf-Breeze, Florida: Environmental Research Laboratory.

Norkrans, B. \& Sörensson, F. (1977). On lipid surface layer - bacterial accumulation in model systems. Botanica marina 20, 473-478.

OxOID Manual (1967). Third edition, pp. 99-103. London: Oxoid Ltd.

Pieterson, W. A., Volwerk, I. I. \& de HaAs, G. H. (1974). Interaction of phospholipase $A_{2}$ and its zymogen with divalent metal ions. Biochemistry 13, 1439-1445.

ProulX, P. \& FunG, C. K. (1969). Metabolism of phosphoglycerides in $E$. coli. IV. The positional specificity and properties of phospholipase A. 
Canadian Journal of Biochemistry 47, 11251128.

ShaH, D. O. \& Schulman, J. H. (1967). Enzymic hydrolysis of various lecithin monolayers employing surface pressure and potential technique. Journal of Colloid and Interface Science 25, 107119.

SHAW, D. J. (1969). Electrophoresis. London: Academic Press.

VERgER, R., RIETSCH, J., VAN DAM-Mieras, M. C. E. \& DE HAAS, G. H. (1976). Comparative studies of lipase and phospholipase $\mathrm{A}_{2}$ acting on substrate monolayer. Journal of Biological Chemistry 251, 3128-3133.

Williams, R. P., Scott, R. H., Lim, D. V. \& QUADRI, S. M. H. (1976). Macromolecular synthesis during biosynthesis by Serratia marcescens. Applied and Environmental Microbiology 31, $70-77$.

Zografi, G., Verger, R. \& de HaAs, G. H. (1971). Kinetic analysis of the hydrolysis of lecithin monolayers by phospholipase A. Chemistry and Physics of Lipids 7, 185-206. 